\title{
The use of Radiation Grafted LDPE for the Removal of Malachite Green Dye from Wastewater
}

Kamal, H. ${ }^{1}$; Hegazy, E.A. ${ }^{1}$; Soliman, E.A. ${ }^{2}$; Shawky, H.A. ${ }^{3}$, Kotp, Y.H. ${ }^{3}$ and Farag, M.H.

Received: 27/12/2017

Accepted: 17/07/2018

E.mail:rosa.rose680@gmail.com

\section{KEYWORDS}

Dye-adsorption;

Adsorption

Isotherm; Kinetic;

Thermodynamic

Studies.

\section{ABSTRACT}

Removal of malachite green dye (MG) from industrial wastewater has been investigated using low density polyethylene (LDPE)-grafted-glycidylmethacrylate (GMA) then chemically modified with diethylamine (DEA), hydroxylamine (HA) or phosphoric acid $\left(\mathrm{H}_{3} \mathrm{PO}_{4}\right)$. The effects of various factors; initial dye concentration, $\mathrm{pH}$, contact time, temperature ...etc on the adsorption process were studied and optimal experimental conditions were ascertained. The adsorption of MG on the prepared adsorbents were confirmed by Fourier Transform Infrared (FTIR) and Scanning Electron Microscopy (SEM). The contact time at equilibrium was found to be 120 minutes at $\mathrm{pH}=5.8$ and temperature $40^{\circ} \mathrm{C}$. Langmuir and Freundlich isotherms were applied to the data obtained at equilibrium. The maximum removal of dye was found to be $98 \%$ for the grafted film treated with phosphoric acid indicating that the prepared films would be a good alternative for the removal of MG dye from wastewater with high efficiency and good tool economically.

1. National Centre for Radiation Research and Technology, Atomic Energy Authority, Egypt, Cairo.

2. Department of Chemistry, Faculty of Science, Ain Shams University, Egypt, Cairo.

3. Desert Research Center. 


\section{INTRODUCTION}

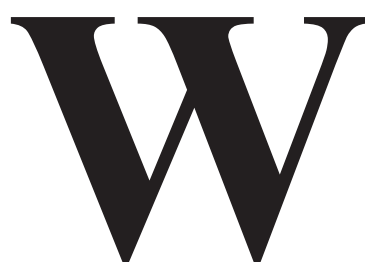

astewater pollution gives adverse effects on the world population of water which may cause health problems such as diarrhea (Gupta et al., 2004) . Dyes have long been used in many industries like: painting, paper and pulp, textiles, plastics, leather, cosmetics, pharmaceuticals and food to color their products ((Sartape et al., 2017) and (Pallavi et al., 2018). Dyes have various conventional methods of removing from wastewaters like: coagulation, electrochemical process, adsorption, membrane separation process, chemical oxidation, reverse osmosis and anaerobic microbial degradation.

Adsorption is a surface phenomenon which results out of binding forces between atoms, molecules and ions of adsorbate and the surface of adsorbent (Parashar, 2012). Among these methods, adsorption is preferred over these treatments and is widely used due to low cost and high efficiency and ease of operation (Min-Yu et al., 2006) and (Malik, 2003). Moreover as the adsorptions of the various adsorbents are not very large, and the new adsorbents which are more economical, easily available and highly effective are still needed so the work is still going on.

The purpose of this work is to determine effectiveness of removing malachite green dye as an example of cationic dye from wastewater using LDPEg-GMA and treated with diethyl amine (DEA), hydroxyl amine (HA) or phosphoric acid $\left(\mathrm{H}_{3} \mathrm{PO}_{4}\right)$. Kinetics and isotherm were also studied in this study.

The MG dye has molecular formula $\left[\mathrm{C}_{23} \mathrm{H}_{25} \mathrm{~N}\right.$ $\left.{ }_{2} \mathrm{Cl}\right]$ and the chemical structure of $\mathrm{MG}$ is shown in( Fig.1) by (Ashis et al., 2017).

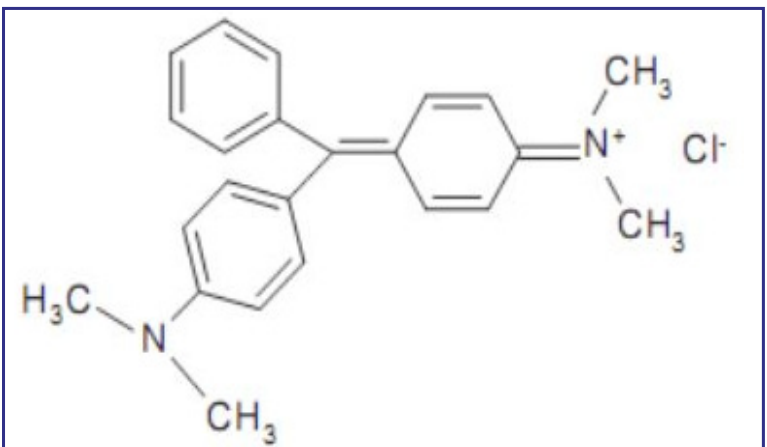

Fig. (1): Chemical Structure of Malachite Green.

\section{MATERIALS AND METHODS}

Malachite green (MG) dye content 90\% from (Alpha-India) were utilized as received, glycidyl methacrylate (GMA) of purity $99 \%$ from (Merck). Diethylamine (DEA); 99\% from (Sigma-Aldrich), hydroxyl amine (HA); 96\% from (Shinyo-Japan), or phosphoric acid $\left(\mathrm{H}_{3} \mathrm{PO}_{4}\right) ; 85 \%$ from (Aldrich). Other chemicals as solvents used, $\mathrm{HCl}, \mathrm{NaOH}$ were provided from (Sigma-Aldrich) and utilized without extra purifications.

\section{Preparation of LDPE Grafted Films}

Strips of Low density polyethylene (LDPE) films with thickness $70 \mu \mathrm{m}$, were provided by (El-Nasr Co. for Medical Supplies, Egypt). LDPE films were cut to the dimension of $(5 \mathrm{~cm} \times 5 \mathrm{~cm})$, weighted and then immersed in (GMA/solvent: $15 / 85 \%$ ) of GMA as a monomer and 1,4-Dioxane as a solvent, then subjected to gamma irradiation from ${ }^{60} \mathrm{Co}$ gamma cell 4000A, produced by the Atomic Energy of India installed at NCRRT, Egypt at a dose rate $2.5 \mathrm{kGy} / \mathrm{h}$ and different doses from 5 to $20 \mathrm{kGy}$. After the irradiation, the grafted films were removed, washed and soaked overnight in acetone to remove the residual monomer and homopolymers. After that were dried in oven at $50^{\circ} \mathrm{C}$ for $24 \mathrm{~h}$ then weighted to a constant weight. The degree of grafting was determined as the 
percentage increase of weight of LDPE films using the following equation:

Degree of Grafting (\%) $=\frac{\mathrm{w}_{\mathrm{g}}-\mathrm{W}_{\mathrm{o}}}{\mathrm{W}_{0}} \times 100$

Where $\mathrm{W}_{\mathrm{g}}$ and $\mathrm{W}_{\mathrm{o}}$ are the weights of LDPEgrafted and ungrafted films, respectively.

\section{Chemical Modification of Grafted Films}

Improvement of the hydrophilic and ion exchange properties of the grafted films was carried out by treating them with DEA, $\mathrm{HA}$ or $\mathrm{H}_{3} \mathrm{PO}_{4}$.

\section{Treatment of Grafted Films with Functional}

\section{Groups}

LDPE-g-GMA films were treated with DEA, $\mathrm{HA}$ or $\mathrm{H}_{3} \mathrm{PO}_{4}$ as adsorbents for removal of MG dye by three different experimentals.

(1). A mixture of 1,4-dioxane and dimethylformamide (DMF) (1:4 v/v), and then $1 \mathrm{ml}$ of DEA was added, (2). LDPE-g-GMA films were soaked in a mixture of alcoholic solution (water/methanol; 50/50 $\mathrm{v} / \mathrm{v})$ containing $6(\%)$ of HA and (3). Phosphonation of LDPE-g-GMA was carried out by immersing the grafted films in $85 \%$ of $\mathrm{H}_{3} \mathrm{PO}_{4}$ aqueous solution. Grafted- treated films were soaked in different reaction mixtures at room temperature in a reflux system. The reactions were carried out at $80^{\circ} \mathrm{C}$ at different time intervals $(2,4,6$ and $8 \mathrm{~h})$ at $\mathrm{pH}$ 7. Then the treated films were washed repeatedly with distilled water to remove the excess reagents and dried in a vacuum oven at $50^{\circ} \mathrm{C}$ for $24 \mathrm{~h}$.

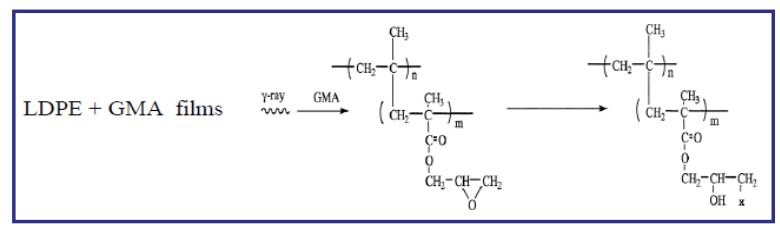

Scheme 1: Preparation of LDPE-g-GMA films treated with DEA, HA or $\mathrm{H}_{3} \mathrm{PO}_{4}$, where: $\mathrm{X}=-\mathrm{N}\left(\mathrm{C}_{2} \mathrm{H}_{5}\right) 2,-\mathrm{NH} . \mathrm{OH}$ or $\mathrm{PO}_{3} \mathrm{H}$.

\section{CHARACTERIZATION OF THE PREPARED ADSORBENTS}

\section{FTIR-Spectrophotometric Measurements}

Mattson 1000 FTIR-spectrophotometer product of Unicom Ltd, England was used to detect the functional groups introduced by grafting and chemical treatment and also to confirm the MG dye adsorption at wavenumber ${ }^{-1}$ range from 4000 to $400 \mathrm{~cm}^{-1}$.

\section{Scanning Electron Microscope Measurements}

The surface topography of the grafted and grafted treated films before and after dye adsorption was studied using JEOL SEM-25 Scanning electron microscope. Prior to, examination, the films were dried under sputter coated gold.

\section{Adsorption Studies}

Batch adsorption was studied for removal of $\mathrm{MG}$ dye onto the adsorbents using UV-spectrophotometer at wavelength $\left(\lambda_{\max }=618 \mathrm{~nm}\right)$.

by varying parameters. The parameters studied include effect of initial dye concentration, effect of $\mathrm{pH}$, effect of contact time and effect of temperature on adsorption of MG dye and maintained shaking at $40 \mathrm{rpm}$.

The amount adsorbed at equilibrium on the different adsorbents $\left(q_{e}, m g / g\right)$ and percentage of removal was calculated by using equations (2) and (3):

$$
\mathrm{q}_{\mathrm{e}}=\left[\left(\mathrm{C}_{\mathrm{o}}-\mathrm{C}_{\mathrm{e}}\right) \times \mathrm{V}\right] / \mathrm{W}
$$

$$
\text { Removal }(\%)=\left[\left(\mathrm{C}_{0}-\mathrm{C}_{\mathrm{e}}\right) / \mathrm{C}_{0}\right] \times 100
$$

Where, $\mathbf{V}$ is the volume of dye solution (L), $\mathbf{W}$ is the weight of dried adsorbent ( $\mathrm{g}), \mathbf{C}_{\mathbf{o}}$ and $\mathbf{C}_{\mathbf{e}}$ are the dye concentrations at initial and equilibrium $(\mathrm{mg} / \mathrm{L})$, respectively. 


\section{RESULTS AND DISCUSSION}

\section{Effect of Solvent}

The choice of solvent is essential to the success of radiation grafting experiments and also on the grafting yield. The solvent added to the monomer will be subjected to radiolysis and thus can contribute to chain initiation. Different solvents are chosen for the grafting of GMA onto LDPE to identify a suitable solvent and the results are shown in Table 1:

Table (1) : Effect of different solvents on the degree of grafting (\%) of GMA onto LDPE.

\begin{tabular}{|c|c|c|}
\hline Solvents & Degree of Grafting (\%) & Remarks \\
\hline Benzene & 28.69 & No homopolymer \\
\hline D.M.F & 79.60 & Moderate homopolymer \\
\hline Methanol & 103.21 & Moderate homopolymer \\
\hline 1,4-Dioxane & 138.22 & No homopolymer \\
\hline Acetone & 184.23 & High homopolymer \\
\hline
\end{tabular}

As can be seen from Table 1, solvent is observed that the percentage of grafting of GMA onto LDPE is higher in acetone and dioxane than other solvents used. However, the high grafting yield obtained in acetone is due to formation of some homopolymer within the grafted samples leading to non-homogeneous grafting. It is observed that, the grafting proceeds homogeneously and appropriate degrees of grafting obtained in the presence of dioxane as a solvent. So that dioxane is chosen as solvent for the grafting of GMA onto LDPE.

\section{Effect of Irradiation Dose}

The effect of irradiation dose on the percentage grafting of GMA onto LDPE films in the presence of dioxane as a solvent are shown in (Fig.2). It is obvious that degree of grafting increases relatively rapidly with increasing irradiation dose while propagation is the main reaction, then slightly decrease after $20 \mathrm{kGy}$, as the termination of graft chains becomes more predominant.

\section{Effect of Monomer Concentration}

The grafting of GMA monomer onto LDPE was investigated at different monomer concentrations in
(Fig.3). It is obvious that the percentage degree of grafting increases with increasing GMA concentration until reaches its maximum value at $15 \mathrm{wt} \%$ due to increasing in free radical and active sites on the polymer/monomer pair, while above $15 \mathrm{wt} \%$, the percentage degree of grafting $\sim$ reaches constant value. So that $15 \mathrm{wt} \%$ was chosen as an optimum monomer concentration.

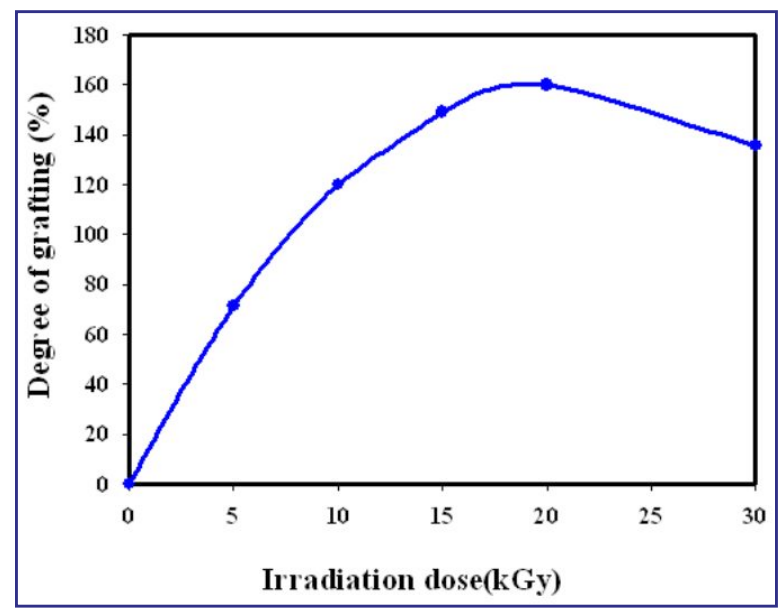

Fig. (2): Effect of irradiation dose on the grafting of GMA onto LDPE films using dioxane as a diluent, monomer concentration; 20wt (\%). 


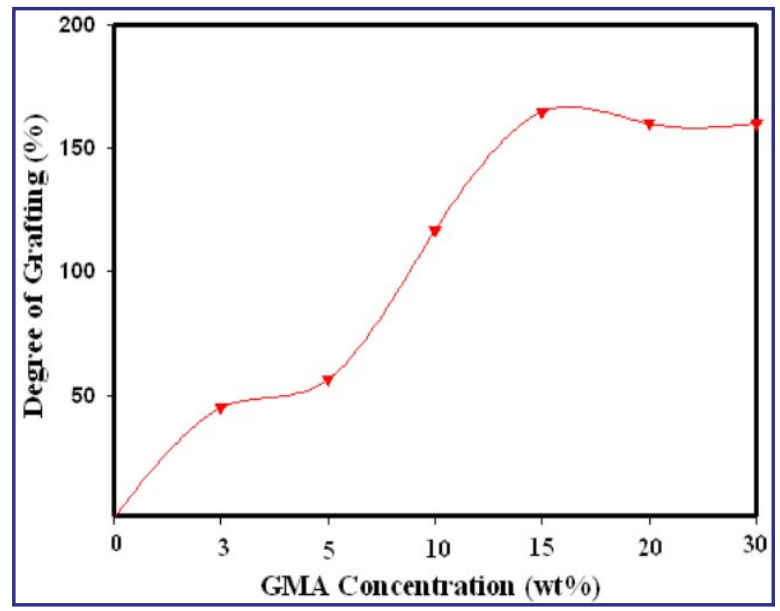

Fig. (3): Effect of monomer concentration on the grafting of GMA onto LDPE films using dioxane as a diluent and irradiation dose; 20 kGy.

\section{CHARACTERIZATION OF GRAFTED TREATED FILMS}

\section{FTIR-Spectra Measurements}

FTIR spectra of LDPE-ungrafted, LDPE-gGMA untreated and the grafted films that treated with DEA, $\mathrm{HA}$ or $\mathrm{H}_{3} \mathrm{PO}_{4}$ are shown in (Fig. 4). From (Fig. 4b), the strong peak observed at $1733 \mathrm{~cm}^{-1}$ is due to $\mathrm{C}=\mathrm{O}$ group stretching vibration and the band at $908 \mathrm{~cm}^{-1}$ is due to asymmetric stretching of the epoxy ring. These results clearly indicate that the introduction of LDPE-g-GMA onto LDPE films is clearly achieved. In the FTIR spectrum of the grafted-treated films (Fig. 4c, d and e), it is obvious that the intensity of the absorption band corresponding to $\mathrm{C}=\mathrm{O}$ groups of grafted-untreated chains was decreased and shifted to $1732.3 \mathrm{~cm}^{-1}, 1729 \mathrm{~cm}^{-1}, 1725 \mathrm{~cm}^{-1}$ after treatment with DEA, HA, or $\mathrm{H}_{3} \mathrm{PO}_{4}$, respectively due to neighboring interaction of functional groups. The band at $908 \mathrm{~cm}^{-1}$ related to epoxy ring is decreased after the treatment with DEA and HA due to ring opining and residual epoxy groups clearly remained (Kimmins et al., 2014). This was proved by the disappearance of epoxy during phosphoric acid treatment. FTIR shows the change in properties and the interactions of functional groups between adsor- bent and adsorbate. It can be seen that $\mathrm{C}=\mathrm{O}$ group of the grafted-treated films with DEA, $\mathrm{HA}$ or $\mathrm{H}_{3} \mathrm{PO}_{4}$ shifted to $1731.7 \mathrm{~cm}^{-1}, 1727 \mathrm{~cm}^{-1}, 1736.3 \mathrm{~cm}^{-1}$, respectively, after MG dye adsorption in (Fig.5). The broad band which assigned to overlapping of $\mathrm{OH}$ and $\mathrm{NH}$ stretching in the grafted-DEA-treated film was shifted to $3008 \mathrm{~cm}^{-1}$ after dye adsorption. The broad band shifting at $3350.10 \mathrm{~cm}^{-1}$ due to the reaction between adsorbent treated with HA and the board band shifting into $3016 \mathrm{~cm}^{-1}$ due to $\mathrm{P}-\mathrm{O}$ in phosphoric acid after dye adsorption. Generally, the shift observed in the characteristic band of the adsorbents after MG dye adsorption is due to introduced new functional groups of MG dye on the sites of adsorbents. The characteristic peaks indicated that the functional group of MG can be adsorbed successfully. This shift in peak values may be due to the formation of chemical bond between functional groups present on the prepared film and $\mathrm{MG}$.

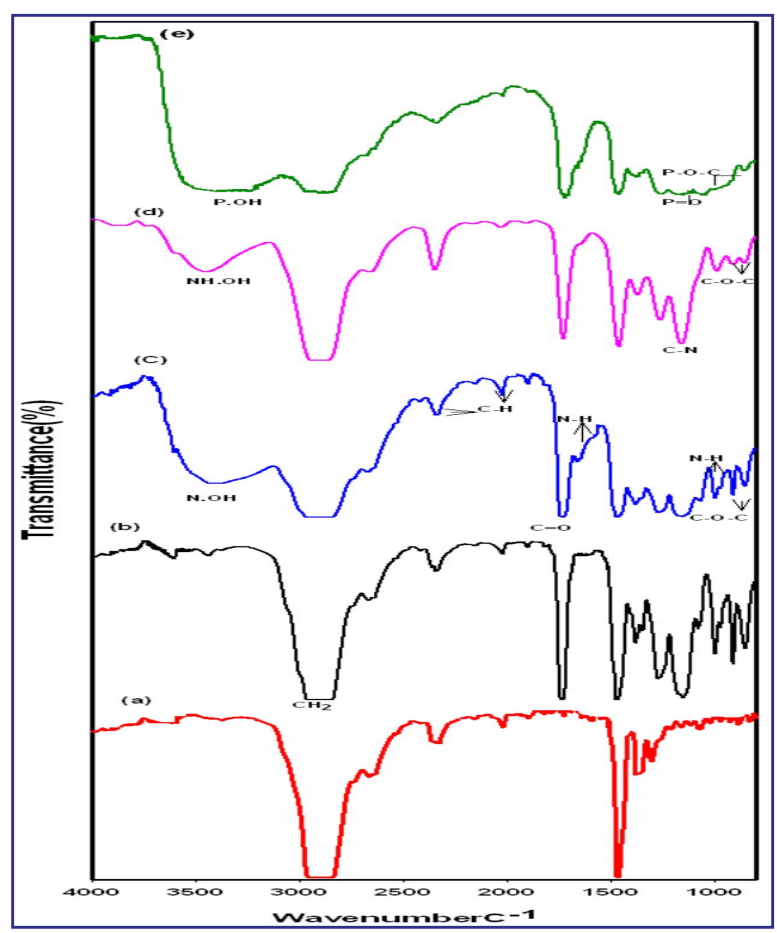

Fig. (4): FTIR spectra of (a)-LDPE ungrafted, (b)-LDPEg-GMA-untreated and LDPE-g-GMA-treated films with (c)-DEA, (d)-HA or (e)- $\mathrm{H}_{3} \mathrm{PO}_{4}$ before dye adsorption. 


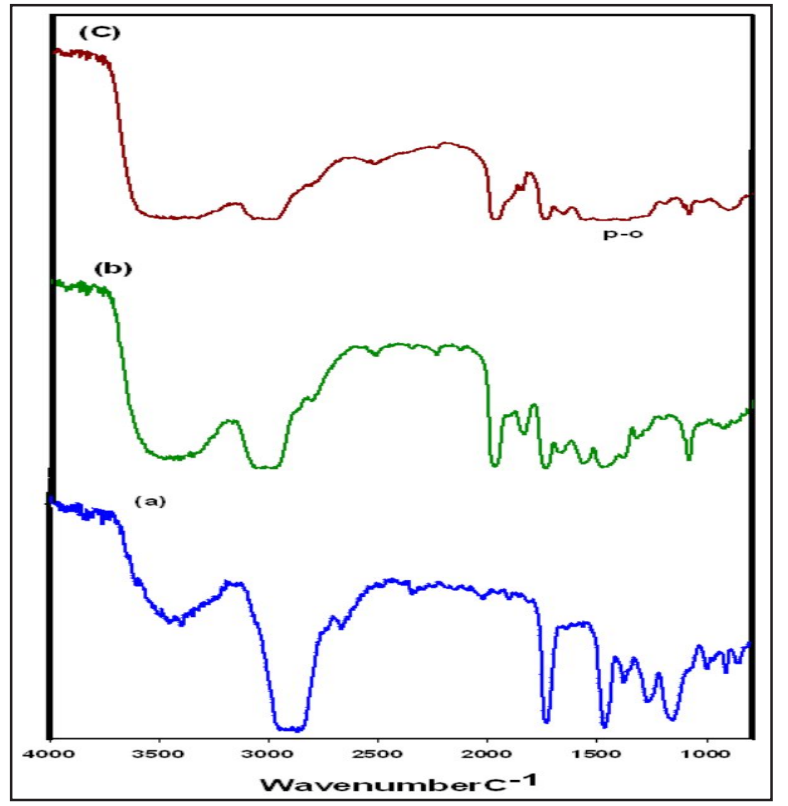

Fig. (5): FTIR spectra of LDPE-g-GMA treated films with (a)-DEA, (b)-HA or (c)- $\mathrm{H}_{3} \mathrm{PO}_{4}$ after dye adsorption.

\section{SEM Microscope}

The surface morphology of the grafted-treated films was investigated by SEM before and after dye adsorption in (Fig.6). This figure showed complete change in surface morphology. Before adsorption there was rough surface morphology as observed (Fig.6.a, b and c). The rough surface of the graftedtreated films can provide a high adsorption capacity, while smoother morphology was observed after adsorption of dye on the surface of adsorbent in (Fig. $6 \mathrm{~d}$, e and f). It can be also noted that the MG dye molecules occupied the pores of the grafted-treated films indicating the adsorption of MG dye by the polymeric adsorbents.

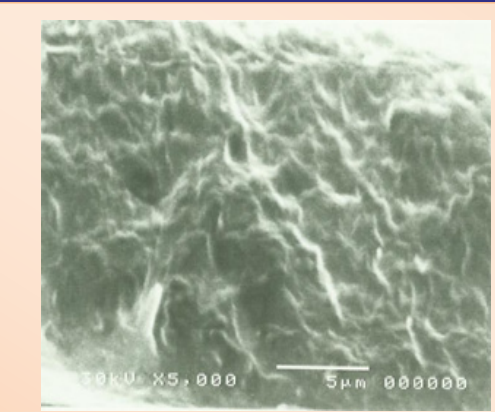

(a)- DEA

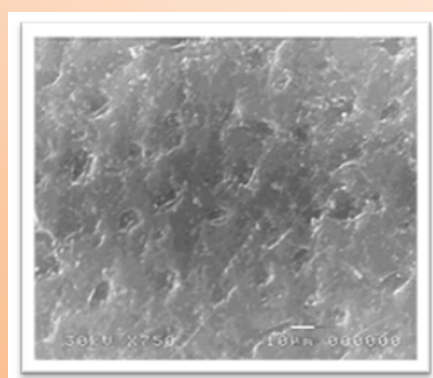

(d)- DEA+MG

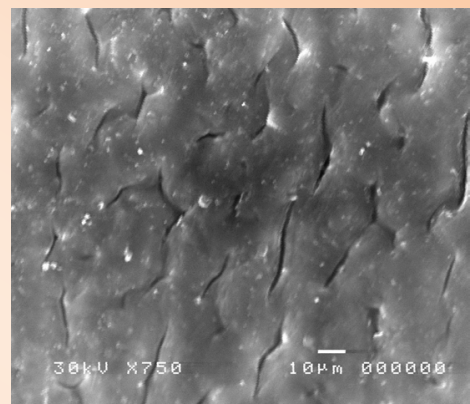

(b)- HA

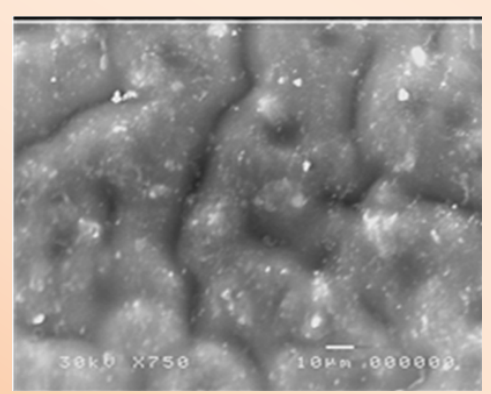

(e)- HA+MG

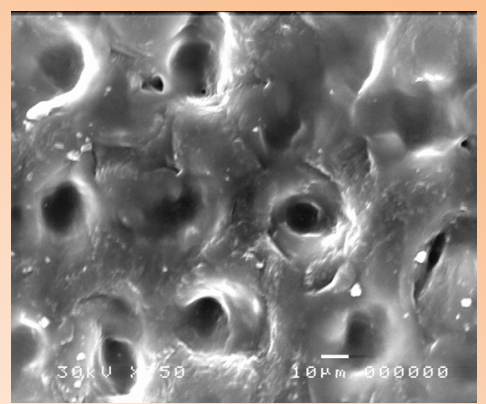

(C)- $\mathrm{H}_{3} \mathrm{PO}_{4}$

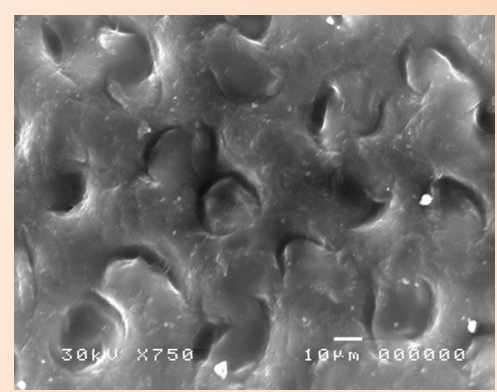

(f)- $\mathrm{H}_{3} \mathrm{PO}_{4}+\mathrm{MG}$

Fig. (6): SEM of LDPE-g-GMA treated films before and after adsorption MG dye. 


\section{Adsorption of Malachite Green Dye:}

The adsorption of MG dye onto the graftedtreated films was investigated spectrophotometrically and the absorbance data obtained were converted into concentration data (Fig.7), showed the standard calibration curve of MG dye.

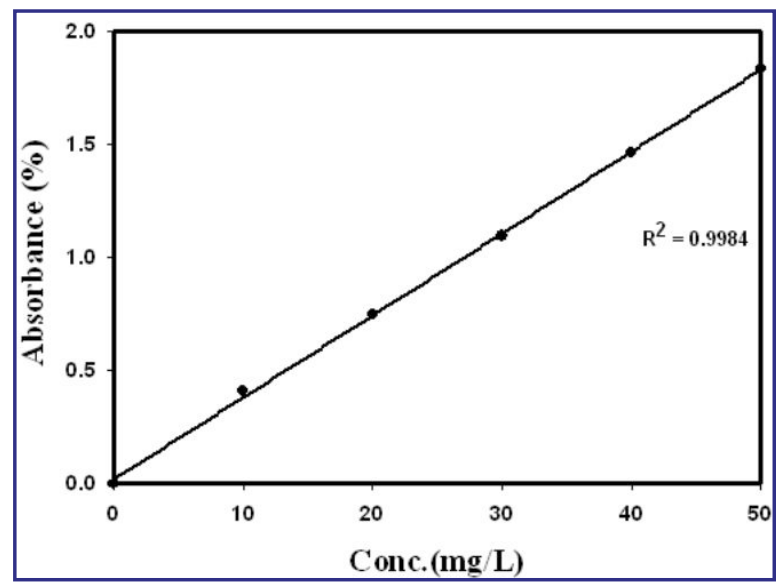

Fig. (7): Calibration curve of MG dye.

\section{Effect of Initial Dye Concentration}

The removal percentage increases with increasing the initial dye concentration of different prepared adsorbents in $50 \mathrm{ml}$ of dye solution with different initial concentrations that ranged from $10-50 \mathrm{mg} / \mathrm{L}$ that shown in (Fig.8). After that, the removal percentage remained constant at dye concentration higher than 40ppm as the active sites become saturated. The increase of the sorption capacity with increasing dye concentration confirmed strong interaction between MG dye and polymer. Increasing the initial concentration enhances the interaction between the dye and adsorbents from providing necessary driving force to overcome the resistances to mass transfer of dye (Sartape et al., 2017).

\section{Effect of $\mathrm{pH}$}

The surface charge depends on the $\mathrm{pH}$ of the solution. Effect of $\mathrm{pH}$ was studied by varying the $\mathrm{pH}$ of the dye solution from 2 to 6 and was adjusted by adding $0.1 \mathrm{M} \mathrm{HCl}$ or $0.1 \mathrm{M} \mathrm{NaOH}$. LDPE-g-GMA treated films as adsorbents were studied in (Fig. 9). It has been observed that the removal percent increases with increasing the $\mathrm{pH}$ of dye solutions up to 5.8, then a saturation state was reached. These results indicated that at lower $\mathrm{pH}$ the dye cations become protonated and a competition may occur between the dye cations and $\mathrm{H}^{+}$for the active sites in the adsorbate by increasing the $\mathrm{pH}$ of the dye solution, the adsorbent become negatively charged and so the cationic dye molecule can be adsorbed and the removal percent increase. It is also obvious that the removal percent for the grafted films treated with phosphoric acid $>$ hydroxyl amine $>$ diethyl amine

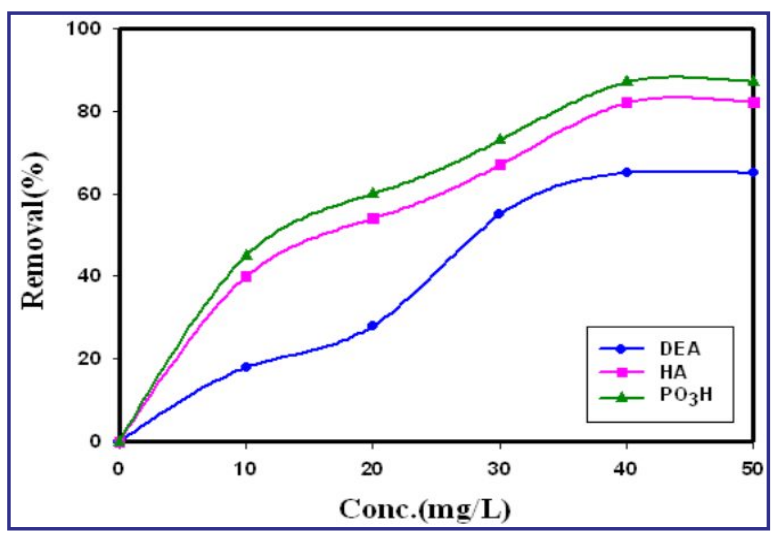

Fig. (8): Effect of initial conc. on the removal (\%) of MG dye, temp. $\sim 25^{\circ} \mathrm{C}, \mathrm{pH} ; 6$ and time; $24 \mathrm{~h}$.

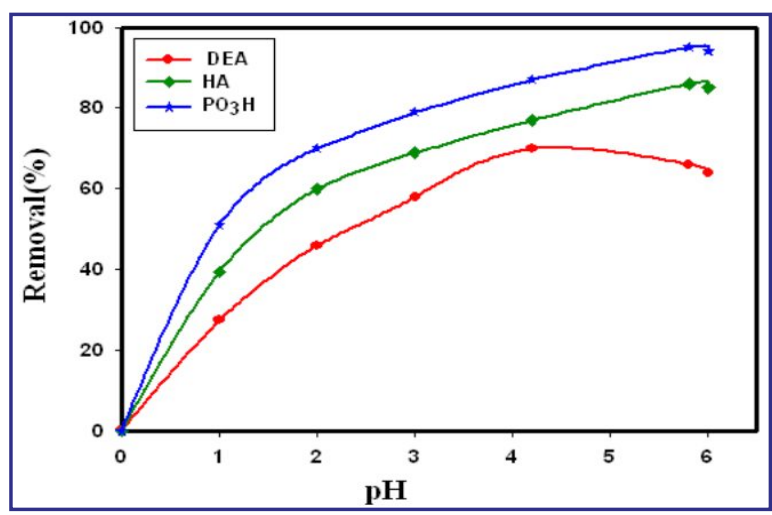

Fig. (9): Effect of $\mathrm{pH}$ on the removal (\%) of MG dye; Conc.; $40 \mathrm{mg} / \mathrm{L}$, temp. $\sim 25^{\circ} \mathrm{C}$ and time; (120 min.). 


\section{Effect of Contact Time}

The effect of contact time on the removal of MG was carried out at various time intervals from 5 to 150 minutes. (Fig.10) showed the removal percent obtained using various time intervals at $\mathrm{pH}=5.8$ and temperature $\sim 25^{\circ} \mathrm{C}$. It is clear that the dye uptake is rapid in the earlier stages of adsorption process and hence the removal percent is high more than $70 \%$ of the initial dye concentration was removed within 20 minutes. These results may be due to that the active sites on the grafted treated films are vacant in the initial stages of the adsorption process. After a rapid initial dye uptake, there was transitional phase in which the rate of dye uptake was slow to reach equilibrium after $2 \mathrm{~h}$. The results showed that more than $90(\%)$ of the initial dye concentration was removed by LDPE-g-GMA treated film with phosphoric acid at the equilibrium.

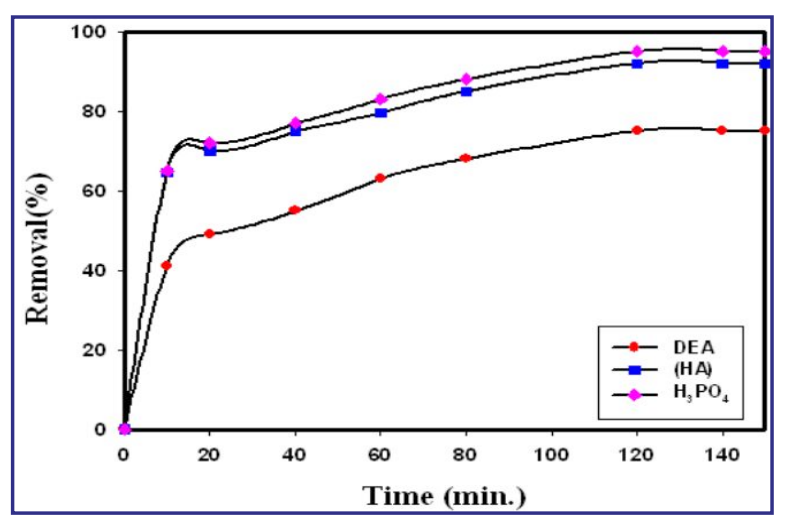

Fig. (10): Effect of contact time on the removal (\%) of MG dye, conc.; 40 (mg/L), temp. $\sim 25^{\circ} \mathrm{C}$ and $\mathrm{pH} ; 5.8$.

\section{Effect of Temperature}

The effect of temperature was studied by varying the temperature between 30 to $50^{\circ} \mathrm{C}$ and the results are shown in (Fig.11). It can be seen that the removal percentage increases with increasing the temperature from 30 to $40^{\circ} \mathrm{C}$ then level off. The results indicated the increase in kinetic energy and the dye molecules may also to undergo an interaction with active sites at the surface of adsorbents. In addition, increasing the temperature may allow the dye molecules to pen- etrate into the grafted-treated film and react with the active sites. It is also obvious that the removal percent for the LDPE-g-GMA treated films with $\mathrm{H}_{3} \mathrm{PO}_{4}$ $>\mathrm{HA}>$ DEA.

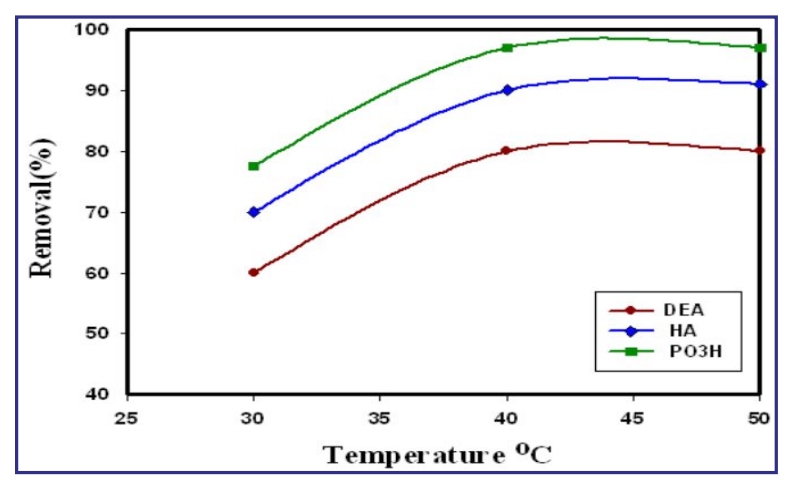

Fig. (11): Effect of temperature on the removal (\%) of $\mathrm{MG}$ dye, conc.; 40 (mg/L), pH; 5.8 and time; (120 min.).

\section{Kinetic Studies on Malachite Green Adsorption}

The kinetics of basic MG dye on the prepared adsorbents was analyzed using the pseudo $1^{\text {st }}$ order and pseudo $2^{\text {nd }}$ order equations.

\section{Pseudo-First-order Kinetic}

Pseudo- $1^{\text {st }}$-order model is given after integration by:

$$
\ln \left(q_{e}-q_{t}\right)=\ln q_{e}-K_{1} t
$$

Where, $\mathrm{q}_{\mathrm{e}}$ and $\mathrm{q}_{\mathrm{t}}$ are the amounts of dye adsorbed by the adsorbent $(\mathrm{mg} / \mathrm{g})$ at equilibrium and at time $\mathrm{t}$ and $\mathrm{K}_{1}\left(\mathrm{~min}^{-1}\right)$ is rate constant of the pseudo first order. In (Fig.12) represents the linear plot of $\ln \left[\mathrm{q}_{\mathrm{e}}-\mathrm{q}_{\mathrm{t}}\right]$ vs $\mathrm{t}$ (Santhi et al., 2015). The correlation coefficient $\left(\mathrm{R}^{2}\right), \mathrm{K}_{1}, \mathrm{q}_{\mathrm{e}}$ (cal) were calculated and the results are shown in Table 2.

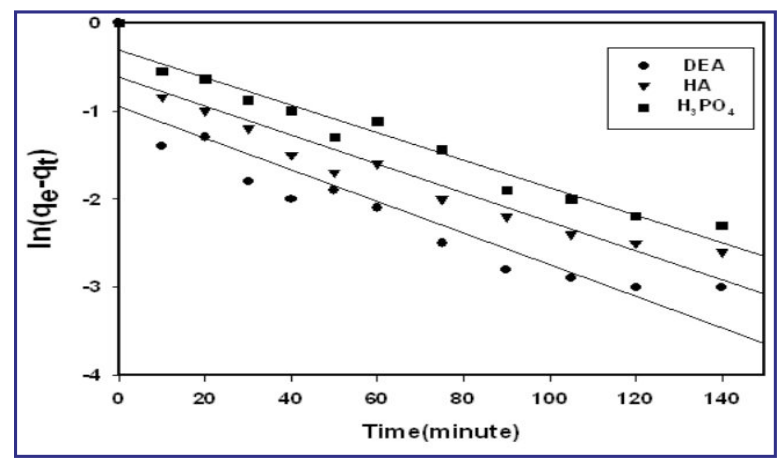

Fig. (12): Pseudo-first-order slope. 
Table (2) : Parameters of Pseudo $1^{S T}$ order.

\begin{tabular}{|c|c|c|c|c|}
\hline LDPE-g-GMA treated films with & $\mathrm{q}_{\mathrm{e}}, \mathrm{cal}(\mathrm{mg} / \mathrm{g})$ & $\mathrm{K}_{1}(1 / \mathrm{min})$. & $\mathrm{q}_{\mathrm{e}}$, exp. & $\mathrm{R}^{2}$ \\
\hline DEA & 3.6 & 0.015 & 8.6 & 0.823 \\
\hline $\mathrm{HA}$ & 5.13 & 0.019 & 14.4 & 0.9005 \\
\hline $\mathrm{H}_{3} \mathrm{PO}_{4}$ & 10.73 & 0.020 & 21.8 & 0.9540 \\
\hline
\end{tabular}

If the value of $\mathrm{q}_{\mathrm{e}}$ cal. $\neq \mathrm{q}_{\mathrm{e}}$ exp. indicating that this model is inapplicable indicating that adsorption of malachite green (MG) onto grafted-treated films did not follow pseudo-first-order kinetics model as the same opinion (Muinde et al., 2017).

\section{Pseudo-Second-order Kinetic:}

The Pseudo- $2^{\text {nd }}$ order model proposed (HO and McKay, 1999) can be represented in the following linear form $(\mathrm{R})$ by:

$$
\mathbf{T} / \mathbf{q}_{\mathrm{t}}=1 / \mathrm{K}_{2}{ }^{*} \mathbf{q}_{\mathrm{e}}{ }^{2}+\mathrm{t} / \mathbf{q}_{\mathrm{e}}
$$

Where, $\mathrm{q}_{\mathrm{e}}$ and $\mathrm{q}_{\mathrm{t}}$ are the amounts of dye adsorbed $(\mathrm{mg} / \mathrm{g})$ at equilibrium and at time $\mathrm{t}$, respectively. $\mathrm{k}_{2}$ is the Pseudo- $2^{\text {nd }}$ rate constant of the adsorption process. (Fig.13) represents the relationship between $t /$ Table (3) : Parameters of Pseudo $2^{\text {nd }}$ order. qt vs t (Sartape et al., 2017).

The correlation coefficient $\left(\mathrm{R}^{2}\right), \mathrm{K}_{2}, \mathrm{q}_{\mathrm{e}}$ was calculated and the results are shown in Table 3 for Pseudo- $2^{\text {nd }}$ order.

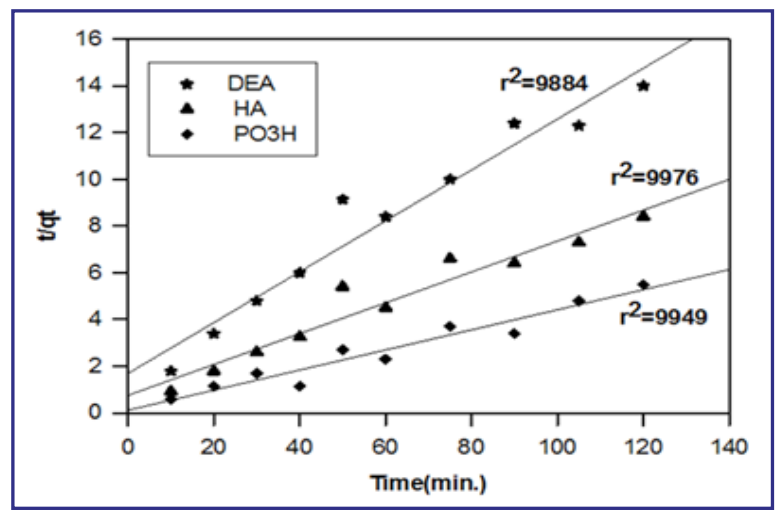

Fig. (13): Pseudo-second-order slope.

\begin{tabular}{|c|c|c|c|c|}
\hline LDPE-g-GMA treated films with & $\mathrm{q}_{\mathrm{e}}$, cal(mg/g) & $\mathrm{K}_{2}(\mathrm{mg} / \mathrm{g}$ min.) & $\mathrm{q}_{\mathrm{e}}$, exp. & $\mathrm{R}^{2}$ \\
\hline DEA & 9.18 & 0.0323 & 8.6 & 0.9884 \\
\hline $\mathrm{HA}$ & 15.15 & 0.0058 & 14.4 & 0.9976 \\
\hline $\mathrm{H}_{3} \mathrm{PO}_{4}$ & 23.25 & 0.016 & 21.8 & 0.9949 \\
\hline
\end{tabular}

Table (3) showed that the pseudo-second order equation was applicable for all adsorbents and the correlation coefficient was $\left(\mathrm{R}^{2}=0.99\right)$. The calculated $\mathrm{q}_{\mathrm{e}}$ values from the model were also in good agreement with the experimental values. The result indicates that the pseudo second order is better than pseudo-first order model for the adsorption of MG. These results are in good agreement with the previous studies as cyclodextrin-based adsorbent (Crini et al., 2007), Pithophora spp. a fresh water algae
(Kumar et al., 2005), carbon (Zhang et al., 2008), NRH nitric acid treated rice husk), PRH (peroxide treated rice husk) (Bendi et al., 2013), and Plumbago Zeylanica (PZ) (Pallavi et al., 2018) were studied to follow the pseudo second-order model.

\section{Adsorption Isotherms}

Langmuir and Freundlich are the widely applied isotherm models. The linear equations are given: 


\section{Langmuir Isotherm}

The Langmuir model is given by:

$$
\mathrm{C}_{\mathrm{e}} / \mathrm{q}_{\mathrm{e}}=1 / \mathrm{K}_{\mathrm{L}} \times \mathrm{q}_{\mathrm{o}}+\left(1 / \mathrm{q}_{0}\right) \mathrm{C}_{\mathrm{e}}
$$

Where, $\mathrm{C}_{\mathrm{e}} / \mathrm{q}_{\mathrm{e}} \mathrm{vs} \mathrm{C}_{\mathrm{e}}$ is plotted, $\mathrm{C}_{\mathrm{e}}(\mathrm{mg} / \mathrm{L}), \mathrm{q}_{\mathrm{e}}(\mathrm{mg} / \mathrm{g})$ are the liquid phase concentration and amount adsorbed at equilibrium, respectively.

$\mathrm{K}_{\mathrm{L}}(\mathrm{L} / \mathrm{mg})$ and $\mathrm{q}_{\mathrm{o}}(\mathrm{L} / \mathrm{mg})$ are the Langmuir constants (Sartape et al., 2017) and can be calculated from the intercept and the slope.

The intercept gives $1 / \mathrm{K}_{\mathrm{L}}$ value and the slope gives $1 / \mathrm{q}_{\mathrm{o}}$ values are shown in (Fig.14). $\mathrm{K}_{\mathrm{L}}$ can be calculated from the intercept and the value of $\mathrm{q}_{\mathrm{o}}$ can be obtained from the slop are shown in Table 4.

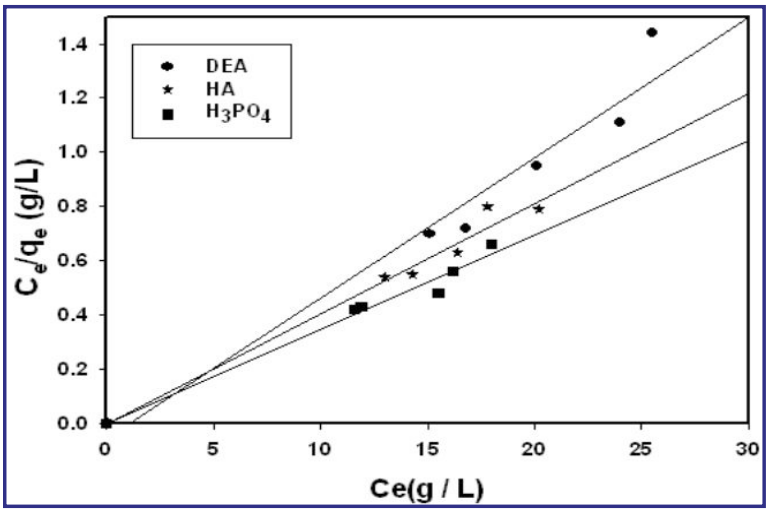

Fig. (14): Langmuir Isotherm Slope.

Table (4) : Parameters of Langmuir Isotherm.

\begin{tabular}{|c|c|c|c|}
\hline LDPE-g-GMA treated films with & $\mathbf{q}_{0}$ & $\mathrm{~K}_{\mathrm{L}}$ & $\mathbf{R}^{2}$ \\
\hline DEA & 0.094 & 11.4 & 0.957 \\
\hline $\mathrm{HA}$ & 0.030 & 24.6 & 0.977 \\
\hline $\mathrm{H}_{3} \mathrm{PO}_{4}$ & 0.015 & 29.4 & 0.979 \\
\hline
\end{tabular}

\section{Freundlich Isotherm}

The Freundlich isotherm model is given by:

$\ln q_{e}=\ln K_{f}+1 / n_{f} \ln C e$

Where: $\mathrm{K}_{\mathrm{f}}$ is the Freundlich constant $\left(\mathrm{L}^{-1} \mathrm{gm}\right)($ Pallaviand et al., 2018), $1 / \mathrm{n}_{\mathrm{f}}$ is the heterogeneity factor. (Fig.15) shows the relationship between $\operatorname{lnC}_{e} v \operatorname{lng}_{e}$. The slope gives $1 / n_{\mathrm{f}}$ value and the intercept gives $\ln$ $\mathrm{K}_{\mathrm{f}}$ value as shown in Table 5 . The heterogeneity factor $1 / n_{f}$ is a measure of the deviation from linearity of the adsorption and ranges between ( 0 and 1$)$ which indicate the degree of non-linearity between solution concentration and adsorption. A higher value of $\mathrm{K}_{\mathrm{f}}$ indicates a higher capacity for adsorption than a lower value (Xiangliang and Zhang., 2009).

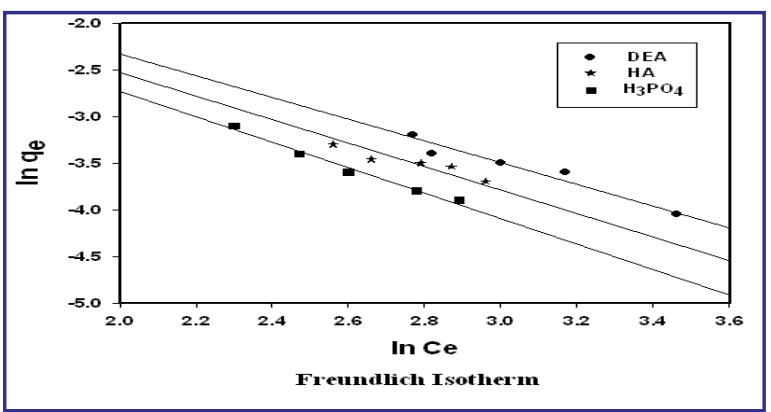

Fig. (15): Freundlich isotherm slope.

Table (5) : Parameters of Langmuir Isotherm.

\begin{tabular}{|c|c|c|c|}
\hline LDPE-g-GMA, treated films with & $\mathrm{K}_{\mathrm{f}}$ & $1 / \mathrm{n}_{\mathrm{f}}$ & $\mathbf{R}^{2}$ \\
\hline DEA & 0.134 & 1.39 & 0.996 \\
\hline $\mathrm{HA}$ & 1.010 & 1.03 & 0.997 \\
\hline $\mathrm{H}_{3} \mathrm{PO}_{4}$ & 1.64 & 0.66 & 0.999 \\
\hline
\end{tabular}


The values of linear $\mathrm{R}^{2}$ coefficient were high of Freundlich isotherm indicating the suitable values of its constants. So, the adsorption isotherm for adsorption MG dye is better by Freundlich model than Langmuir model as the same opinion result (Dhahir et al., 2013).

\section{Thermodynamic Studies}

The thermodynamic studies play an important role in understanding the heat change in the adsorption process. The effect of temperature of the adsorbents on the adsorption of MG was investigated at 323, 313, $303 \mathrm{~K}$. Thermodynamic parameters, such as change in enthalpy $\left[\Delta \mathrm{H}^{\circ}\right]$, entropy $\left[\Delta \mathrm{S}^{\circ}\right]$ and Gibb's free energy $\left[\Delta \mathrm{G}^{\circ}\right]$ were investigated using the equations (8) \& (9):

$$
\begin{aligned}
& \ln K_{\mathrm{C}}=\frac{\Delta S^{\circ}}{R}-\frac{\Delta H^{\circ}}{R} \frac{1}{T} \\
& \Delta G^{\circ}=-\mathrm{RT} \ln K_{\mathrm{C}}
\end{aligned}
$$

The negative values of $\Delta \mathrm{G}^{\circ}$ presenting in the Table 6 , indicates that physisorption is dominating the weak chemical interactions as said by (Pallavi et al., 2018), and with increase in temperature, the negative values of $\Delta \mathrm{G}^{\circ}$ decreases indicated the spontaneous adsorption process.

Table (6) : Values of thermodynamic parameters.
Where, standard enthalpy $\left(\Delta \mathrm{H}^{\circ}\right)$, standard entropy $\left(\Delta \mathrm{S}^{\circ}\right)$ and Gibbs free energy $\left(\Delta \mathrm{G}^{\circ}\right), \mathrm{Kc}$ is constant, $(\mathrm{R}=8.314 \mathrm{~J} / \mathrm{mol} \mathrm{K})$ and $\mathrm{T}$ is the absolute temperature (K) were agreed by (Sartape et al., 2017) and (Pallavi et al., 2018). The $\Delta \mathrm{H}^{\circ}$ and $\Delta \mathrm{S}^{\circ}$ were calculated from the linear Van't Hoff plot i.e. In Kc vs. 1/T showed in (Fig.16).

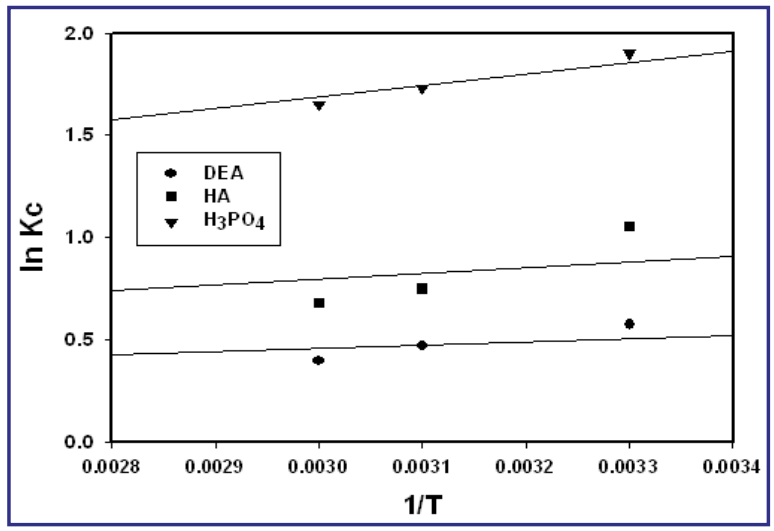

Fig. (16): Van't Hoff plots for adsorption of MG on LDPE g-GMA treated films with DEA, HA or $\mathrm{H}_{3} \mathrm{PO}_{4}$.

The values of $\Delta \mathrm{H}^{\circ}$ and $\Delta \mathrm{S}^{\circ}$ were calculated from the slope $\left[-\Delta H^{\circ} / R\right]$ and the intercept $\left[\Delta \mathrm{S}^{\circ} / \mathrm{R}\right]$ of the plots of $\ln \mathrm{Kc}$ vs $1 / \mathrm{T}$ (Santhi et al., 2015). The $\Delta \mathrm{H}^{\circ}$ values of grafted-treated films are presented in Table 6 and the negative value of $\Delta \mathrm{H}^{\circ}$ indicated the exothermic process.

\begin{tabular}{|c|c|c|c|c|}
\hline Temperature (K) & $\begin{array}{c}\Delta G^{\mathrm{o}}(\mathrm{kJ} / \mathrm{mol}) \\
\text { DEA }\end{array}$ & $\begin{array}{c}\Delta \mathrm{G}^{\mathrm{o}}(\mathrm{kJ} / \mathrm{mol}) \\
\mathrm{HA}\end{array}$ & $\begin{array}{c}\Delta \mathrm{G}^{\mathrm{o}}(\mathrm{kJ} / \mathrm{mol}) \\
\mathrm{H}_{3} \mathrm{PO}_{4}\end{array}$ & $\Delta \mathrm{H}^{\mathrm{o}}(\mathrm{kJ} / \mathrm{mol})$ at $(313 \mathrm{~K})$ \\
\hline 303 & -4.089 & -7.435 & -15.346 & DEA= $=1.28$ \\
\hline 313 & -3.841 & -6.985 & -14.416 & $\mathrm{HA}=-2.24$ \\
\hline 323 & -3.71 & -6.750 & -13.951 & $\mathrm{H}_{3} \mathrm{PO}_{4}=-4.65$ \\
\hline
\end{tabular}

\section{CONCLUSION}

Batch adsorption experiments show that the adsorption of MG dye onto LDPE-g-GMA and treated with DEA, HA or $\mathrm{H}_{3} \mathrm{PO}_{4}$ was dependent on many variables including contact time, $\mathrm{pH}, \mathrm{MG}$ concentration, and temperature. Type of chemical treatment i.e. type of functional group, has an important role in the adsorption process. Freundlich model was best fit the isotherm data and Pseudo second order kinetics followed the kinetic values. Thermodynamic analysis indicated that the adsorption of $\mathrm{MG}$ dye onto grafted-treated films was exothermic and 
spontaneous. The removal $(\%)$ at $40^{\circ} \mathrm{C}$ is found to be $80(\%)$ for DEA, $89(\%)$ for HA and $98(\%)$ for $\mathrm{H}_{3} \mathrm{PO}_{4}$, respectively. It can be concluded that the LDPE-g-GMA that treated with $\mathrm{H}_{3} \mathrm{PO}_{4}$ is more efficient adsorbent for MG dye than other films since its removal dye efficiency reached $98(\%)$.

\section{REFERENCES}

- Ashish, S.S.; Aniruddha, M.M.; Vikas, V.J.; Prakash, D.R.; Mansing, A.A. and Sanjay, S.K. (2017): Removal of malachite green dye from aqueous solution with adsorption technique using Limonia acidissima (wood apple) shell as low cost adsorbent. Arab J., Chem., 10: 3229.

- Bendi, R.; Pathpireddy, M.; Reddy, K. and Challapalli, S. (2013): Low cost adsorbents from agricultural waste for removal of dyes. Environ. Prog. Sustain. J., 33(1):38.

- Chetna, P. (2012): Removal of Malachite Green dye by adsorption using char. Rourkela NIT J., $108 \mathrm{CH} 036$.

- Crini, G.; Peindy, H.N.; Gimbert, F. and Robert, F. (2007): Removal of C.I. Basic Green 4 (Malachite Green) from aqueous solutions by adsorption using cyclodextrin-based adsorbent: kinetic and equilibrium studies. Sep. Purif. Technol. J., 53 (1): 97.

- Gupta, V.K.; Mittal, A.; Krishnan, L. and Gajbe, V. (2004): Adsorption kinetics and column operations for the removal and recovery of malachite green from wastewater using bottom ash. Sep. Purif. Technol. J., 40: 87 .

- Ho, Y.S. and Mckay, G.A. (1999): A kinetic study of dye sorption by biosorbent waste product pith. Resour. Conserv. Recy. J., 25 (3): 171.

- Kumar, K.V.; Sivanesan, S. and Ramamurthy, V. (2005): Adsorption of malachite green onto Pithophora sp., a fresh water algae: Equilibrium and kinetic modeling. Process Biochem. J., 40 (8), 2865.

- Malik, P.K. (2003): Use of activated carbons prepared from sawdust and rice-husk for adsorption of acid dyes: a case study of Acid Yellow 36. Dyes Pigments J., 56:239.

- Min-Yu, T. and Su-Hsia, L. (2006): Removal of methyl orange dye from water onto raw and acid activated montmorillonite in fixed bed. Desalin. J., 201: 71.

- Muinde, V.M.; Onyari, J.M.; Wamalwa, B.; Wabomba, J. and Nthumbi, R.M. (2017): Adsorption of malachite green from aqueous solutions onto rice husks: Kinetic and equilibrium studies. AJEP J., 8: 215.

- Pallavi, P.; King, P. and Prasanna, Y. (2018): Use of plant biomass for removal of malachite green from aqueous solution and optimization using Central Composite Design (CCD). Rasayan J. chem., 11 (1): 203.

- Saadiyah, A.D.; Enaas, A.H.; Sanaa, T.S. and Noor, F. (2013): Adsorption of malachite green dye from aqueous solution onto iraqi raw al-hussainiyat deposit. ECB J., 2 (11): 866.

- Santhi, M.; Kumar, P.E. and Muralidharan, B. (2015): Removal of malachite green dyes by adsorption onto activated carbon- $\mathrm{Mno}_{2}-\mathrm{Nanocomposite}-$ Kinetic study and equilibrium isotherm analyses. IOSR J. AC., 8: 33.

- Scott, D.K.; Paul, W. and Neil, R.C. (2014): Aminefunctionalization of glycidyl methacrylate-containing emulsion-templated porous polymers and immobilization of proteinase $\mathrm{K}$ for biocatalysis. Polymer J., 55 (1): 416.

- Xiangliang, P. and Daoyong, Z. (2009): Removal of malachite green from water by Firmiana simplex wood fiber. Electron. J. Biotechn., 12 (4): 997.

- Zhang, J.; Li Y.; Zhang, C. and Jing, Y. (2008): Adsorption of malachite green from aqueous solution onto carbon prepared from Arundo donax root. Hazard. Mater. J., 150 (3): 774. 


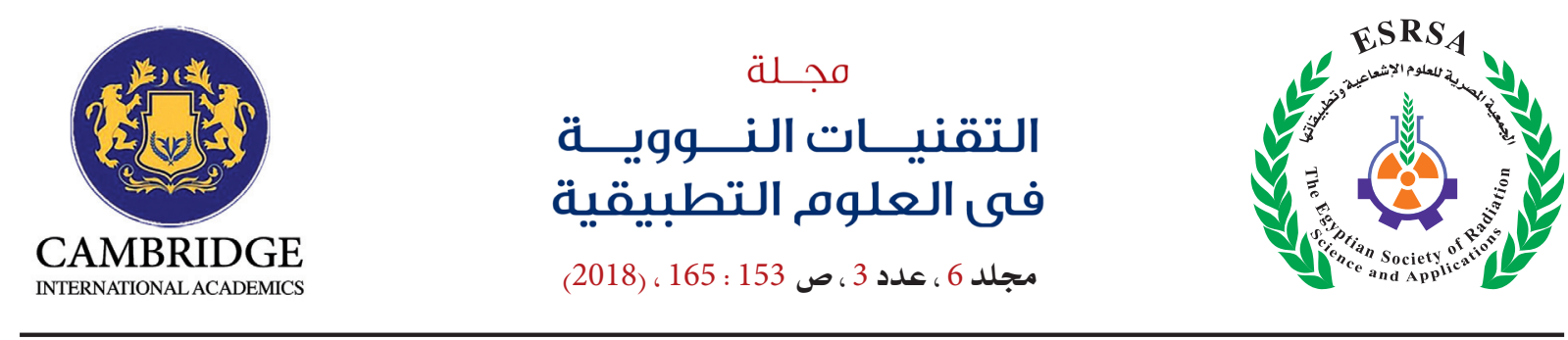

استخدام البولى اثيلين المنخفض الكثافت المطعم باستخدام الاشعاع لإزالت صبغت

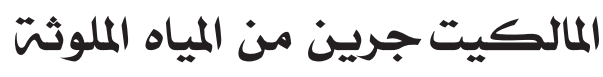

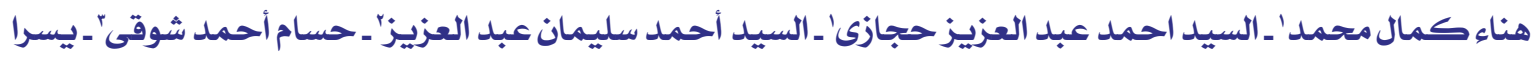

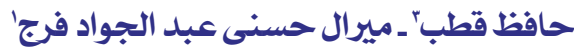

تمت دراسه تحضير بعض الآغشيه الصناعيه ذات المجموعات الوظيفيه لإزالت صبغت الملاكيت جرين من مياه الصرف الصناعي وذلك بالتطعيه الآشعاعي لأفلام البولي إثيلين

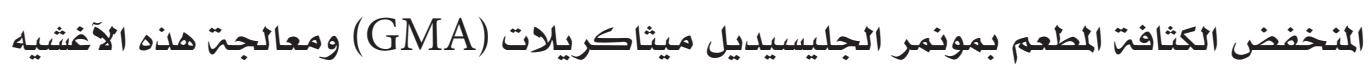

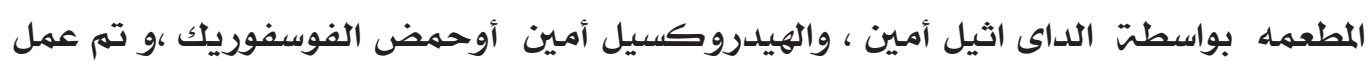

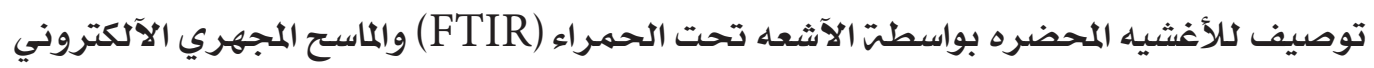

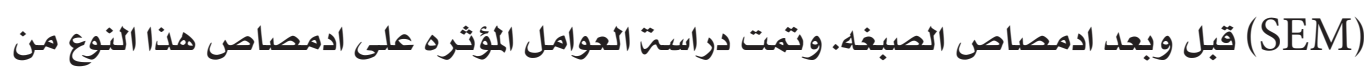
الصبغات مثل تأثير التركيز الآولي وزمن التلامس ودرجت الحموضتّ ودرجت الحرارة للصبغه. و أسفرت هذه الدراسـه على أن الزمن الكلازم للوصول الى ازالت معظم الصبغنه والتى تصل الى نسبت

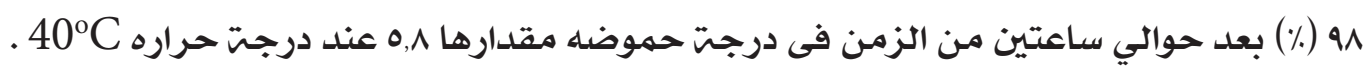
ونستنتج من هذه الدراسـه أن الآغشيه المحضره سوف تكون بديلا جيدا للهمتزات الآخرى لآزالت صبغن الملاكيت جرين ومايشابهها من صبغات بمياه الصرف الصناعي بكفاءه عاليه وكأداه جيده اقتصاديا. 
